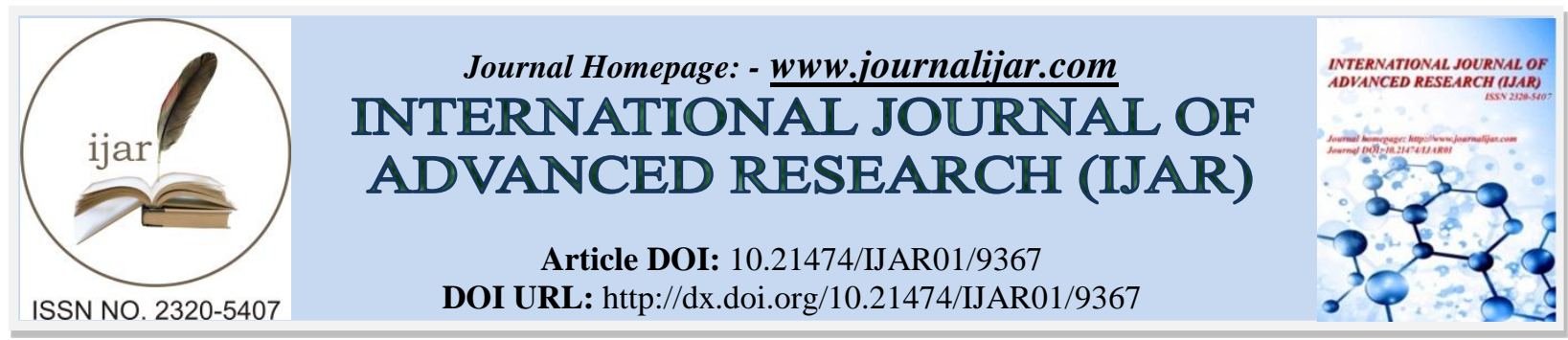

RESEARCH ARTICLE

\title{
ANALYSIS OF DEVELOPING TECHNOLOGICAL PEDAGOGICAL AND CONTENT KNOWLEDGE OF SCIENCE TEACHERS: A REVIEW.
}

Lailatul Fitri Fauziah, Slamet Hariyadi, Erlia Narulita.

Department of Science Education, University of Jember, Jember, Indonesia 68121.

\section{Manuscript Info}

Manuscript History

Received: 10 May 2019

Final Accepted: 12 June 2019

Published: July 2019

Key words:-

Technological, Pedagogical and Content Knowledge (TPACK), science teacher, qualified teachers.

\begin{abstract}
This article discusses the importance of Technological, Pedagogical and Content Knowledge (TPACK) in science learning in the 21st century. Technological Pedagogical Content and Knowledge (TPACK) is currently considered as an important knowledge for highly qualified teachers . TPACK describes the knowledge synthesized from each field of knowledge with a focus on how technology can be tailored to be faced with pedagogical needs to teach the right content in a particular context. Teachers ' pedagogy thinking skills affect the basic knowledge of teachers needed to develop TPACK. The writing of this article was conducted through a systematic review of the articles relating to the Use of the Pedagogical Content and Knowledge (TPACK) problem in science teachers. Sorting articles used in this review was by reading abstract and content. The result of sorting, obtained 16 best articles. There were three phases in conducting qualitative data analysis, namely: (1) data reduction, (2) The data feed, and (3) the withdrawal of conclusions. The TPACK on contextual factors and pedagogical reasoning of the teacher affects the ability of teachers to enact their classes and what they learn in school. Teachers ' pedagogy thinking skills affect the basic knowledge of teachers needed to develop TPACK. A teacher educator should be more stressed on how teachers integrate technology in their teaching practice rather than emphasizing what teachers integrate in teaching practice Their. In summary, it is important to integrate TPACK to improve the professionalism of science teachers.
\end{abstract}

Copy Right, IJAR, 2019,. All rights reserved.

\section{Introduction:-}

In the 21st century, it demands the world of education to improve and produce quality human resources. The most important challenge in education this century is to discover and develop an efficient tool and can help in the process of teaching and learning. It can be achieved if supported by technology. Technology must be used in conjunction with education and teaching that cannot be separated from each other (Schmidt, et al., 2008). The technology used can support the implementation of classroom learning as a teacher's instructional cognitive tool, learning and learning process, and effective teaching. Effective teachers know not only the subject matter but are also able to create a learning environment that stimulates and implements pedagogical strategies, including strategy-rich technology to engage students while To help improve their performance (Sahin, 2011). Teachers and students are very important in new technologies that will be used both to collect, organize and evaluate information to solve a 
problem. In improving teacher learning potential and active students ' involvement in science learning, students need not only the sophisticated learning process, but teachers also need to prepare to acquire teaching competencies By integrating technology into teaching practice in classrooms.

Studies conducted on technological integration have highlighted that technological knowledge should be considered along with the knowledge of content and knowledge of pedagogy. Teachers are not only required to have Pedagogic, Content, Knowledge (PCK) skills but also technological application. So that technology, pedagogic and content has become a part of teacher education program to prepare professional teachers. To prepare the competence of the 21st century science teacher, Technological Pedagogical Content and Knowledge (TPACK) is currently considered as an important knowledge for highly qualified teachers. TPACK is an interaction and communication among all three types of knowledge, there are a few interconnected components: technological knowledge, pedagogical, and content (field) (Koehler, et al., 2007). Technological knowledge refers to the knowledge of the standard technology and the high-end technologies used for educational and teaching purposes (Koehler, et. al., 2007). Pedagogical knowledge includes the development of teaching strategies, classroom management, lesson plans, and situations such as student assessments and the nature of mass targets (Hernandez, 2014). Content knowledge involves structures in related fields that connect cases and events, concepts, theories, processes, thoughts and opinions related to the field and organize them.

TPACK as a pedagogical technique that utilizes technology constructively to teach the content, and the knowledge of what makes the concept difficult or easy to learn how technology can help the problems faced by students; students ' initial knowledge and epistemology theories, as well as knowledge of how technology can be used to build existing knowledge and to develop new epistemology or reinforce the old (Kocoglu, 2009), to realize development of science teachers ' ability, teachers must be able to understand cognition and have different ways of learning. Teachers should also be able to understand the students' progress and various pedagogic concepts as well as they master the Learning materials and their alternate assessments that they use to measure student learning outcomes. Thus, teachers are able to place different language and cultural differences, learning styles, talents, and intelligence as the basis for implementing the various teaching strategies he chooses (Abidin, 2009).

Therefore, the author raises the problem regarding the ability of pedagogic technology and content knowledge (TPACK) on the development process of teachers especially for science teachers.

\section{Research Methods:-}

The writing of this article was conducted through a systematic review of the articles relating to the Use of the Pedagogical Content and Knowledge (TPACK) problem in science teachers. Sorting articles used in this review is by reading abstract and content. The result of sorting, obtained 16 best articles from national and international articles. There are three phases in conducting qualitative data analysis, namely: (1) data reduction, carried out with several stages namely: the electoral phase, simplification of the abstraction, review, and transformation of data obtained from the review of articles already exists, (2) The data feed, the data obtained does not contain things that are irrelevant to the research and (3) the withdrawal of conclusions, this stage to record the patterns, regularity, and linkage between section one with the other (Marsigit, 2012).

\section{Results and Discussion:-}

\subsection{Technological Pedagogical and Content Knowledge (TPACK)}

Based on the review of the article that has been done explained that before Technological Pedagogical Content Knowledge (TPACK) first started from the discovery of Pedagogical Content Knowledge (PCK) which appeared in Shulman article in In 1986. Shulman states the combination of Pedagogical Knowledge and Content Knowledge is required to teach. According to Shulman, Pedagogical Content Knowledge (PCK) of a teacher is essential to create useful learning for students. Speaking of Pedagogical Content Knowledge (PCK), there are two major parts that make up Pedagogical Content Knowledge (PCK), Content Knowledge (CK) and Pedagogical knowledge (PK). According to Shulman (1986), content knowledge includes knowledge of concepts, theories, ideas, skeletal thinking, proving methods and evidence. While pedagogical knowledge relates to ways and teaching processes that include knowledge of classroom management, assignment, learning and learning planning of students. Pedagogical Content Knowledge (PCK) can be described as a link between the basic knowledge of content and pedagogy with all three required fields of context. Then Hurrel (2013) depicted the Shulman's idea as follows: 


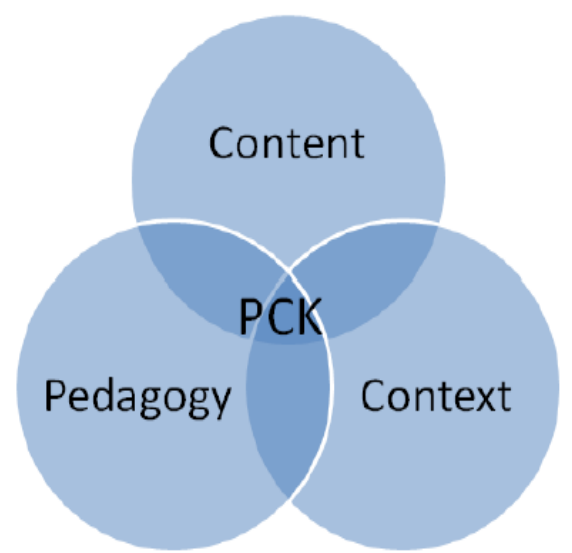

Figure 1:-Shulman's (1986) domains of pedagogical content knowledge

From the picture above, it is seen that Pedagogical Content Knowledge (PCK) is a combination of Content knowledge and Pedagogical Knowledge that teachers apply in learning in the classroom by observing the existing context. Furthermore, when information and communication technology develops very rapidly and began to enter the school evenly, the children began to use information and communication technology in its daily life, it is time teachers implement information technology and communication in its learning. But integrating information and communication technologies into learning is a challenge that is not easily encountered. To answer the challenge, an important theoretical framework that arises today in the use of information technology and communication by the teacher is Technological Pedagogical Content Knowledge (TPACK).

The idea of Technological Pedagogical Content Knowledge (TPACK) appeared formally on the Education journal in 2003 and began to be crowded with the year 2005 which was originally abbreviated to TPCK but changed to TPACK to facilitate the pronunciation (Chai , et al., 2013). Technological Pedagogical Content Knowledge (TPACK) is a technological knowledge, content knowledge, and Pedagogical knowledge, explaining the interaction between every two knowledge and among all the knowledge.

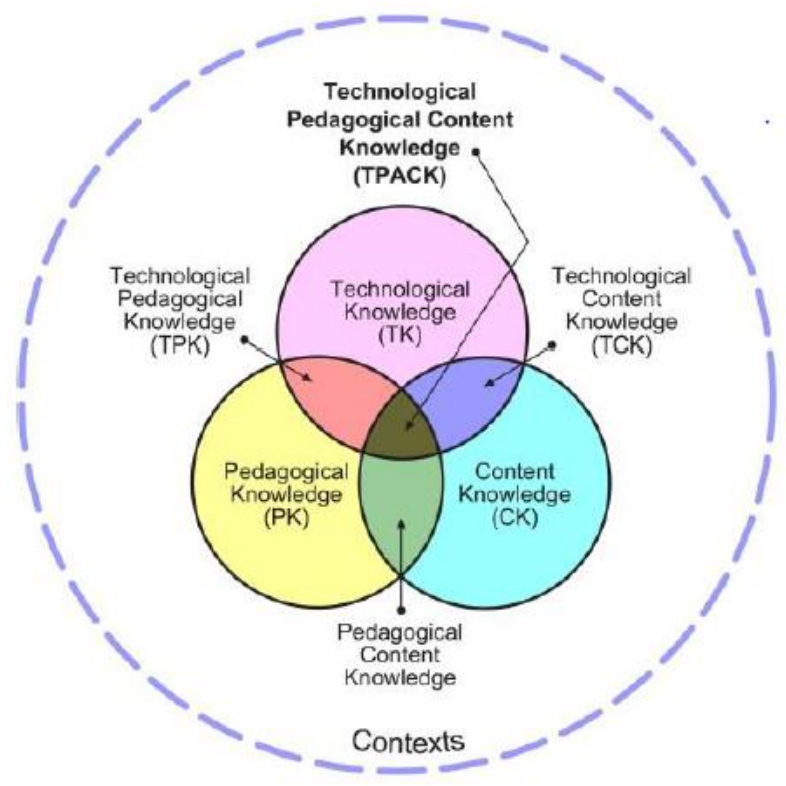

Figure 2:-Kohler`s (2013) TPACK Framework

Technological Pedagogical Content Knowledge (Figure 2) describes the knowledge that is synthesized from every knowledge that has been outlined before focusing on how technology can be made with special to be faced with the needs of to teach the right content in a particular context. Every element of the field of knowledge illustrates the 
need and importance of such aspects in teaching. But for effective teaching requires more than every part of it. For teachers with Technological Pedagogical Content Knowledge (TPACK), technological knowledge, pedagogy, and content are synthesized and used for the design of student learning experiences.

\subsection{Technological Pedagogical and Content Knowledge (TPACK) analysis on science teacher Development} TPACK is an effective teaching basis with technology. Simultaneously integrating knowledge about technology, pedagogy and content, teachers can bring TPACK at any time to their teaching environment. TPACK is able to foster the ability of science teachers in competency and transformation knowledge. TPACK is able to produce high quality science teachers, TPACK competence can be used as the main attribute for the future of science teachers because it can affect the practice (Srisawasdi, 2012). Several other studies have mentioned that TPACK is divided into TPACK's trust and TPACK level. TPACK trusts are used as predictors, while TPACK levels are used to form a case study. The results of the case study showed that there was a positive relationship between the TPACK trust and TPACK level. TPACK's belief systems are consistently associated with their TPACK levels in some respects. When epistemological beliefs are not considered, the relationship between other research variables demonstrates consistency with previous research findings relating to the relationship between self and the conception of teaching and learning (Gunes, 2016).

In another study, the introduction of the TPACK framework for science education, found results that $90 \%$ of preservice teachers thinking unit experiments increased their understanding of the investigation process, $88 \%$ reported more confidence in their understanding About the concept of science and 94\% of students report increased knowledge and their belief in WEB 2.0 tools in favor of scientific investigation in science. The TPACK Model provides a curriculum designer with a frame that leads to a combination of technology, pedagogy and content for knowledge. Pre-Service teachers are able to explore issues that exist beyond the narrow reach of science and into society, geography and history by using a science investigation process to frame their investigation (Sheffield, 2015). Guzey (2009) states that the use of TPACK has a positive impact on the various levels of teacher development. The TPACK on contextual factors and pedagogical reasoning of the teacher affects the ability of teachers to enact their classes and what they learn in school. Teachers ' pedagogy thinking skills affect the basic knowledge of teachers needed to develop TPACK. In this case it can be seen that there is a link between the development of TPACK teachers with pedagogical and their reasoning skills. Through pedagogical reasoning the teacher can reflect their pedagogical action. Teachers give reviews of class instruction closely related to their scientific conception, effective teaching of science and instructional strategies, teaching goals and student understanding.

Other findings also indicate that most of the TPACK is associated with the disclosure of practical problems. However, when further investigation is conducted, the orientation of the existing teachers appears more prominent in the conversations in the learning process. In addition, when dealing with TPACK or PCK, most design talks reflect the reflection of concern. Pedagogy is aimed not as a single domain of knowledge, but rather relates to two other domains, so practical implications are discussed for how TPACK is able to support teachers during collaborative design.

TPACK will produce effective ICT innovations, so the composition of the design team needs to be carefully considered. Teachers also need to develop competencies, facilitate and discuss the design so that contextual concerns can be turned into opportunities to support a pedagogic increase. These results indicate that in order to improve TPACK co-construction, the teachers need to be consciously for deeper discussions about pedagogical. However, factors such as class level and ICT competence of students need to be conducted further examination. The results showed that even with the time prescribed for lesson planning, primary teachers 1 could still approach pedagogical innovations through administration lenses.

Based on data analysis in the field indicating the presence of TPACK instruments that have been filled by the participants, participants identify and divide the concept of material into simple content into a more meaningful form of representation (Chamichael, et al., 2010). Participants use methods of learning discussions, information, introductions, and assignments in the classroom. In that method, participants use projector, whiteboard, markers, laptops, and CD players to support the process of discussions that students are doing by displaying student-generated PowerPoint and some video impressions that play using CD player to support the conception of content in students. During the discussion, students are guided by teachers on difficult materials, so that they can explain themselves about the phenomenon of the phenomena contained in the content by using their PowerPoint impressions with video 
support to deepen the concept of material Students. Participants use the learning method of discussion so that students can dig out their own knowledge and discover the concepts themselves. In addition, participants also facilitated students using impressions that students and videos have made to help realize the difficulties found by the students. Based on the TPACK components that have been outlined, the ability of the participant's TPACK is included in the degree category as the participants can identify the difficulties of the content and are able to identify the teaching methods according to technology. However, participants cannot explain how to use technology to change content.

TPACK instruments that have been filled by the teachers show that the skills of SCIENCE teachers in the planning of TPACK on the concept of material is taught mostly in the form of presentations and class discussions. This is due to the 2013 curriculum which demands that students be able to find concepts in the material. In addition, the supporting technology in the presentation and class discussion process is just a set of projector to show the PowerPoint created by the group of students, although there are some teachers who use video and animation for support in the process His studies. In the process of learning, SCIENCE teachers only act as facilitators in the classroom. If any material is deemed difficult, the teacher will begin directing students to find its difficulties and provide a perception of difficult content so that students feel easy and eventually overcome the difficulties in the concept independently.

Based on the analysis of TPACK instruments that have been filled by the teachers, the ability of science teachers in the implementation of TPACK components in the class belongs to the category of level of perception (Perception Level-Pn). At this level of perception, the teacher already has a perception towards the harmonization of TPACK components because through presentation and discussion, the teacher is able to identify the difficulties of the content so that it can transform it into a simple form of content with Support of the appropriate use of technology, which is a set of projector, video, and animated impressions. This shows that science teachers can identify content difficulties and are able to identify the teaching methods that are appropriate to the technology. But teachers, cannot explain how to use technology to change the content teachers will provide to students, so that teacher knowledge is only centered on the use of projector, video, and animated impressions in the teaching process that teachers do in class.

Based on the explanation above, with Technological Pedagogical Content Knowledge (TPACK) affects the teacher. It remembers the relationship between technology, pedagogy, and inherent content. Therefore, teachers face major challenges in shifting technological changes, pedagogy, subject matter and current class contexts. Teachers should have become more active in designing the curriculum. In addition to the impact on teachers, Technological Pedagogical Content Knowledge (TPACK) also affects teacher educators. Among the various learning approaches, a teacher educator should be more stressed on how teachers integrate technology in their teaching practice rather than emphasizing what teachers integrate in teaching practice Their. The approaches that can be done include learning technology by design and learning technology by activity types. The development of Technological Pedagogical Content Knowledge (TPACK) should begin with a variety of simple technologies known then gradually improved to the more sophisticated ones.

\subsection{Factors affecting Science Teacher's TPACK capability}

One of the factors that affects the ability of TPACK is the many learning experiences that teachers obtain through seminars held by the Government in order to improve the quality of teachers. So that the duration of teaching experience is not directly proportional to the increase of TPACK capability. This can be influenced by many factors, such as the busyness of the senior teachers, causing senior teachers to not be able to do their time to learn new things, especially the technological advances in Support the teaching process in the classroom. Therefore, most of the senior teachers are still implementing many conventional methods of learning. In contrast, teachers with a 11-15year teaching experience can still perform transformations in its class using technology. This is because the busyness of teachers who have a teaching experience of 11-15 years, not as much as the busyness that is owned by teachers who have experience of teaching 16 years or more.

\section{Conclusion:-}

The most important challenge in education in the 21 st century is to find and develop an efficient tool and can assist in the teaching and learning process. It can be achieved if supported by technology. The technology used can support the implementation of classroom learning as a teacher's instructional cognitive tool, learning and learning process, and effective teaching. Effective teachers know not only the subject matter but are also able to create a learning environment that stimulates and implements pedagogical strategies, including strategy-rich technology to 
engage students while to help improve their performance. Thus, technology, pedagogic and content has become a part of teacher education program to prepare professional teachers. Technological Pedagogical Content and Knowledge (TPACK) is currently considered as an important knowledge for highly qualified teachers. TPACK describes the knowledge synthesized from each field of knowledge with a focus on how technology can be tailored to be faced with pedagogical needs to teach the right content in a particular context.

\section{References:-}

1. Abidin, Y. 2009. Qualty Teacher and Learning. Bandung: Rizqi Press.

2. Carmichael, A., Chini, J.J., Robello, N.S., Puntambekar, S. 2010. Comparing Student Learning in Mechanics Using Simulation and Hand-on Activities. Physics Education Research Conforence. Vol 1289 pp: 89-92.

3. Chai, C. -S., Koh, J. H. -L., \& Tsai, C. -C. 2013. A Review of Technological Pedagogical Content Knowledge. Educational Technology \& Society. Vol. 16 (2), 31-51.

4. Gunes, Erhan and Bahciva,Eralp. 2016. A Multiple Case Study of Preservice Science Teachers' TPACK: Embedded in a Comprehensive Belief System. International Journal Of Environmental \& Science Education. Vol 11 (15) pp: 8040-8054.

5. Guzey, S. Selcen and Gillian, H.Roehrig. 2009. Teaching Science with Technology: Case Studies of Science Teachers' Development of Technology, Pedagogy, and Content Knowledge. Contemporary Issues in Technology and Teacher Education. Vol 9(1) pp: 25-45.

6. Hernandez, Yosua. 2014. Analysis of Technology Pedagogy Content Knowledge (TPCK) Skill of Biological Teachers of the Pekanbaru High School. Journal of Biogenesis. Vol. 11 (11).

7. Hurrell, D. P. 2013. What Teachers Need to Know to Teach Mathematics: An Argument for a Reconceptualised Model. Australian Journal of Teacher Education Volume 38, Issue 11, Page 54-64.

8. Koehler, M. J., Mishra, P., \& Yahya, K. 2007. Tracing the development of teacher knowledge in a design seminar: Integrating content, pedagogy and technology. Computers \& Education, 49(3), 740-762.

9. Koehler, M. J., Mishra, P., Ackaoglu, M.,\&Rosenberg, J. M. 2013. The Technological Pedagogical Content Knowledge Framework for Teachers and Teacher Educators. Commonwealth Educational Media Centre for Asia.

10. Kocoglu, Z. 2009. Exploring The Technological Pedagogical Content Knowledge of Pre-service Teachers in Language Education. Procedia Social and Science [Online], Vol. 1 (2734-2737).DOI: 10 . 1016 / j . sbspro . 2009. 01.485 .

11. Marsigit, M. A. 2012. Research Study (Internasional Journal Review) Mathematics Education. Yogyakarta: Universitas Negeri Yogyakarata.

12. Sahin, I. 2011. Development of Survey of Technological Pedagogical Content Knowledge (TPACK). The Turkish Online Journal of Technological Education. 10: 97-105.

13. Schmidt, D., Baran Sahin, E., Thompson, A., \& Seymour, J. 2008. Developing effective technological pedagogical and content knowledge (TPACK) in PreK-6 teachers. Proceedings of Society for Information Technology \& Teacher Education International Conference (pp. 5313-5317). Chesapeake, VA: AACE.

14. Shulman, L. S. 1986. Those who understand, knowledge growth in teaching. EducationalResearcher Vol. 15, No, 2, Page 4-14.

15. Sheffield, Rachel., Eva, Dobozy., David, Gibson., Jim, Mullaney and Chris Campbell. 2015. Teacher education students using TPACK in science: a case study. Educational Media International. ISSN: 0952-3987.

16. Srisawasdi, N. 2012. The Role of TPACK in Physics Classroom: Case Study of Preservice Physics Teachers. Thailand. Procedia Social and Behavioral Sciences. 